\title{
Wellbeing and older adults in primary health care in Poland
}

\author{
Aleksandra Błachnio ${ }^{1, A-E}$, Leszek Buliński ${ }^{2, A-B, D-F}$ \\ ${ }^{1}$ Kazimierz Wielki University, Bydgoszcz, Poland \\ ${ }^{2}$ Ateneum University, Gdańsk, Poland \\ A - Research concept and design, B - Collection and/or assembly of data, C - Data analysis and interpretation, \\ $D$ - Writing the article, $E$ - Critical revision of the article, $F$ - Final approval of article
}

Błachnio A, Buliński L. Wellbeing and older adults in primary health care in Poland. Ann Agric Environ Med. $2019 ; 26(1)$ : 55-61. doi: $10.26444 / a a e m / 85711$

\begin{abstract}
Introduction and objective. The Polish health service is in need of improvement because of the increasing number of geriatric patients. Identifying the resources available to patients is important for ameliorating deficits. The goal of this research was to measure the health and wellbeing of seniors and to investigate to what extent health services meet their needs. Differences in access and scope of received services between patients from different localities (i.e villages, small towns and big cities) were analysed.

Materials and method. Questionnaires (Satisfaction with Life Scale; VAS Numeric Pain Distress Scale) and a structured interview assessing the quality of healthcare were carried out in 2015 on a sample of 459 seniors. Each candidate gave consent for participation in the study. Statistica 12.5 software was used for analyses.

Results. The overall measure of satisfaction with life of the respondents $(M=22.34 S D=5.78)$ was good. Inhabitants of small towns had a significantly lower sense of quality of life than seniors from big cities (Tukey HSD $=0.047, p<.05$ ). Multimorbidity and polypharmacy were present to a limited extent. The issue of discrimination of older individuals by medical personnel affected a fifth of seniors living in villages, and one- third of those living in big cities. Geriatric patients did not have equal opportunities for access to medical services.

Conclusions. State-provided geriatric care is insufficient and does not meet the real needs of patients. A holistic care approach and/or individualized care for older adults are often indicated but are only theoretical constructs in Poland. This inefficient system places the burden of caregiving on the family of the ageing patient. Anxiety among geriatric patients is growing regarding exclusion and lack of care.
\end{abstract}

\section{Key words}

quality of life, psychogeriatrics, patient care, attitudes to health, comorbidity, geriatric health services

\section{INTRODUCTION}

Population ageing and its consequences for the health sector have been well-established and broadly discussed in literature $[1,2]$. In particular, studies focus on the problem of chronic diseases [3], which influence the social, psychophysical, and economic dimensions of an individual's life for many years, sometimes even for decades [4]. The movement of health care towards older patients leads to a reorganisation of the structure of health institutions and their adaptation to cater for geriatric patients $[5,6]$. Statistics show that Polish health policies are over a dozen years behind with regards to the needs of the ageing society [7]. In comparison, in the UK there are two geriatric specialists for every 100,000 patients. These standards are out of reach in Poland. If Poland were to match the UK, it would need 760 such specialists, whereas there are currently only 414 [8], most of whom are not even employed in geriatric care [9].

Fulfilling the need for long-term and multifaceted care for geriatric patients [10] on an institutional level has a series of obstacles, such as the aforementioned deficit of specialised personnel and lack of financing for the full scope of the needed health services. On a global scale, ways of saving money are sought in reeducating societies, which is promoted by the

Address for correspondence: Aleksandra Błachnio, Kazimierz Wielki University in Bydgoszcz, Chodkiewicza 30, 85-064 Bydgoszcz, Poland

e-mail: aleksandra.blachnio@gmail.com

Received: 23.10.2017; accepted: 24.02.2018; first published: 24.04.2018
World Health Organisation (WHO), in order to prolong the years of healthy living, or programmes for successful ageing at home, and telemedicine. In Poland, the statistics are not optimistic and show that the lengthening lifespan is associated with high indices of disability, multimorbidity, and polypharmacy [11].

\section{OBJECTIVE}

The aim of this study is to understand the wellbeing of older adults in relation to the real level of resources devoted to Polish geriatric patients (individual and environmental), and to discuss if the data correspond to declared reforms in geriatric practice. The authors investigated differences in terms of the scope and accessibility of care depending the patient's locality, wellbeing, and health. The study was conducted among the inhabitants of cities, towns, and villages.

\section{MATERIALS AND METHOD}

This questionnaire-based study was conducted in 2015 on a sample of 459 older individuals, with an average age of 74.32 $(S D=6.35, \max =93, \min =65)$. Availability sampling was used. Respondents were recruited from the whole of Poland, but the biggest concentration of participants were from the Greater Poland and Kuyavian-Pomeranian provinces. The aim of the 
measurements was to verify quality of life, health, and access to health services of senior individuals living in different areas: big cities $(n=128)$, small towns $(n=187)$, and villages $(n=144)$ (Tab. 1). The questionnaires were completed in a oneon-one setting, and each individual was first informed about the aims of the study, their rights, and asked to give consent to participate. Respondents filled-in the Satisfaction with Life Scale (SWLS) developed by Diener, Emmons, Larsen, and Griffin [12], and adapted for use in Poland by Juczyński [13]. Participants were asked to indicate their level of agreement with each of five statements on a 7-point Likert-type scale $(1=$ strongly disagree to $7=$ strongly agree). According to the SWLS, higher scores indicate greater life satisfaction. Subjects also filled the 0-10 VAS Numeric Pain Distress Scale. Next, a structured interview was conducted in which seniors were asked about their access to health and help services as well as their multimorbidity and polypharmacy status. The gathered data were analysed by means of StatSoft, Inc. (2017) using Statistica, version 12.5 software. For the purpose of statistical analysis, the measure of descriptive statistics, correlation matrix, and analysis of variance were used. The level of statistical significance was assumed at $\mathrm{p}<0.05$.

Table 1. Socio-demographic characteristics of the study sample.

\begin{tabular}{|c|c|c|}
\hline & $\begin{array}{c}\text { Men } \\
(n=86)\end{array}$ & $\begin{array}{l}\text { Women } \\
(n=373)\end{array}$ \\
\hline Age (average, standard deviation) & $70.34(5.67)$ & $75.24(6.15)$ \\
\hline \multicolumn{3}{|l|}{ Marital status $(n, \%)$} \\
\hline Married & $48(55.81 \%)$ & $142(38.07 \%)$ \\
\hline Widowed & $27(31.40 \%)$ & $185(49.60 \%)$ \\
\hline Divorced & $4(4.65 \%)$ & $20(5.36 \%)$ \\
\hline Single & $7(8.14 \%)$ & $18(4.83 \%)$ \\
\hline No data & - & $8(2.14 \%)$ \\
\hline \multicolumn{3}{|l|}{ Education $(n, \%)$} \\
\hline Elementary & $9(10.47 \%)$ & $101(27.08 \%)$ \\
\hline Vocational & $37(43.02 \%)$ & $101(27.08 \%)$ \\
\hline Secondary & $27(31.40 \%)$ & $113(30.29 \%)$ \\
\hline Higher & $12(13.95 \%)$ & $57(15.28 \%)$ \\
\hline No data & $1(1.16 \%)$ & $1(0.27 \%)$ \\
\hline \multicolumn{3}{|l|}{ Household $(n, \%)$} \\
\hline Social welfare institution & $26(30.23 \%)$ & $35(9.38 \%)$ \\
\hline Living alone & $7(8.14 \%)$ & $88(23.59 \%)$ \\
\hline Living with family & $10(11.63 \%)$ & $96(25.74 \%)$ \\
\hline Living with husband/wife & $40(46.51 \%)$ & $145(38.87 \%)$ \\
\hline No data & 3 (3.49\%) & $9(2.41 \%)$ \\
\hline \multicolumn{3}{|l|}{ Locality } \\
\hline Big City & $28(32.56 \%)$ & $100(26.81 \%)$ \\
\hline Small town & $38(44.19 \%)$ & $149(39.95 \%)$ \\
\hline Village & $20(23.25 \%)$ & $124(33.24 \%)$ \\
\hline
\end{tabular}

\section{RESULTS}

First, the overall measure of participants' satisfaction with life was analysed (Tab. 2). The mean score on the SWLS was 22.34 , with a standard deviation of 5.78. Women $(M=22.51$, $S D=5.59)$ and men $(M=21.63, S D=6.54)$ did not differ statistically $(H S D=0.317)$.
Table 2. Seniors' satisfaction of life (SWLS) $(N=459)$

\begin{tabular}{ccccccc}
\hline & Mean & Mode & $\begin{array}{c}\text { Mode } \\
\text { quantity }\end{array}$ & Minimum & Maximum & $\begin{array}{c}\text { Standard } \\
\text { deviation }\end{array}$ \\
\hline SWLS & 22.34 & 25 & 41 & 5.00 & 35.00 & 5.78 \\
\hline
\end{tabular}

Analysis of differences in mean scores for satisfaction with life of inhabitants of big cities, small towns, and villages gave significant results only for the comparison between big cities and small towns. The Tukey HSD=0.047 for $p<.05$ (Fig. 1).

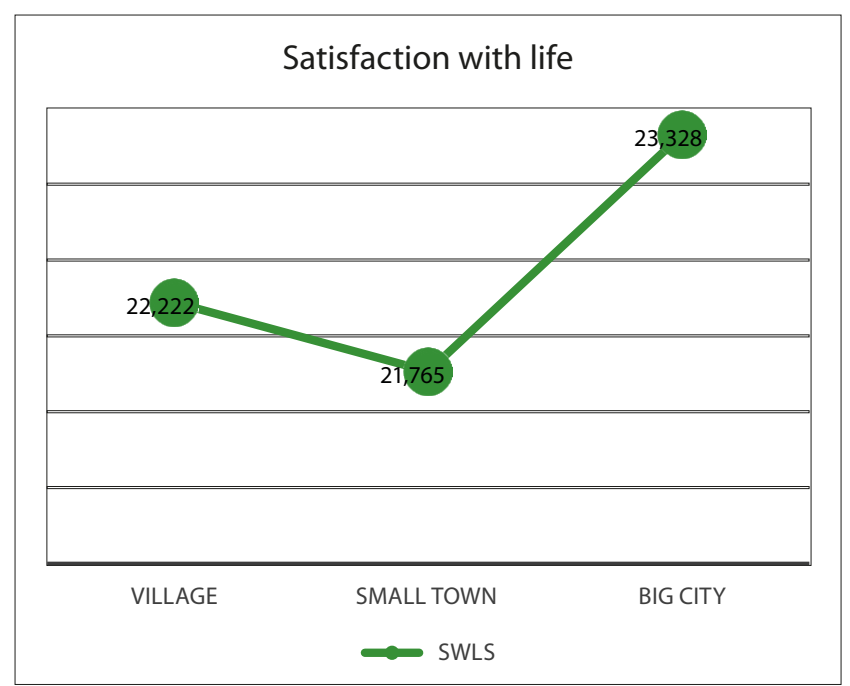

Figure 1. Satisfaction with life of ageing individuals, by locality

The quality of functioning of older adults was assessed with regard to the number of diagnosed disease entities, regularly taken medication, as well as a subjective measure of experienced physical pain. The data showed that individual experience of old age is very varied, ranging from cases of fit and healthy old age (no diseases, no medication, and no experienced physical pain) to disabled and diseased old age (a 70- year-old man with 10 diseases, polypharmacy, and high levels of pain). The collected data proved rather low to moderate levels of multimorbidity and polypharmacy (Tab. 3).

When multimorbidity was assessed, the information on the number of diagnosed diseases was based on self-report. In subgroups of those in their sixties, those in their seventies, and those above eighty, it was found that in the youngest group $(n=154)$ the mean number of diagnosed diseases was $1.46(S D=1.09)$. Among the seventy-year-olds $(n=202)$, these values were $M=1.78(S D=1.32)$ and for those aged eighty and older ( $n=103) M=1.99(S D=1.19)$ (Tab. 4).

Analysis of correlation of factors influencing quality of ageing was in line with the tendencies found in the literature: an increase of multimorbidity and polypharmacy with age, together with a corresponding greater experience of pain. These variables negatively correlate with the overall measure of quality of life (SWLS) and level of education. Education for ageing, with an emphasis changing lifestyles in order to limit unhealthy habits and building new, pro-health behaviours, is justified from this point of view. In Poland, where pro-health education develops dynamically in Universities of the Third Age, such actions seem to be particularly promising. Aalyses showed no statistically significant relationship between the investigated variables and the area of residence - i.e. 
Table 3. Multimorbidity, polypharmacy, and pain - subjective assessment by seniors

\begin{tabular}{lcccccccccc}
\hline & N & M & Median & Mode & $\begin{array}{c}\text { Mode } \\
\text { quantity }\end{array}$ & Min & $\begin{array}{c}\text { Max } \\
\text { quartile }\end{array}$ & $\begin{array}{c}\text { Upper } \\
\text { quartile }\end{array}$ & $\begin{array}{c}\text { Standard } \\
\text { deviation }\end{array}$ \\
\hline Multimorbidity & 459 & 1.72 & 1.00 & 1.00 & 176 & 0 & 10 & 1.00 & 2.00 & 1.23 \\
\hline Polypharmacy & 459 & 1.54 & 1.00 & 1.00 & 197 & 0 & 7 & 1.00 & 2.00 & 1.07 \\
\hline 0-10 VAS Numeric Pain Distress Scale & 423 & 3.36 & 3.00 & 0.00 & 53 & 0 & 10 & 1.00 & 5.20 & 2.63 \\
\hline
\end{tabular}

Table 4. Multimorbidity in successive decades of life of seniors

\begin{tabular}{lccccccccc}
\hline \multirow{2}{*}{ Age Range } & \multicolumn{10}{c}{ No. of Diagnosed Diseases } \\
\cline { 2 - 10 } & 0 & 1 & 2 & 3 & 4 & 5 & 6 & 7 & 10 \\
\hline $60-69$ & 21 & 73 & 40 & 11 & 8 & 0 & 0 & 1 & 0 \\
\hline $70-79$ & 25 & 72 & 57 & 28 & 15 & 4 & 0 & 0 & 1 \\
\hline $80+$ & 8 & 31 & 32 & 21 & 9 & 1 & 1 & 0 & 0 \\
\hline
\end{tabular}

big city, small town, or village. A negative correlation was observed between pathological indices of ageing and the level of autonomy of life of seniors. The autonomy was lower among the residents of nursing homes, and higher among seniors living in households shared with a spouse (Tab. 5).

Table 5. Correlation matrix for variables describing health and quality of life of seniors $(N=413 ; p<.05)$

\begin{tabular}{lccccccc}
\hline & M & SD & Age $\begin{array}{c}\text { Edu- } \\
\text { cation }\end{array}$ & $\begin{array}{c}\text { Ageing } \\
\text { in one's } \\
\text { own } \\
\text { home }\end{array}$ & $\begin{array}{c}\text { Area of } \\
\text { Residence }\end{array}$ & SWLS \\
\hline $\begin{array}{l}\text { 0-10 VAS Numeric } \\
\text { Pain Distress Scale }\end{array}$ & 3.34 & 2.63 & 0.17 & -0.13 & -0.23 & -0.01 & -0.27 \\
\hline Multimorbidity & 1.72 & 1.22 & 0.21 & -0.11 & -0.18 & 0.08 & -0.20 \\
\hline Polypharmacy & 1.55 & 1.05 & 0.21 & -0.12 & -0.14 & 0.08 & -0.18 \\
\hline
\end{tabular}

Together with age and increasing number of chronic diseases, the level of functional independence of seniors decreases together with their quality of life, as shown in the correlation matrix (Tab. 6).

Table 6. Correlation matrix for functional independence and age, multimorbidity, and seniors' satisfaction of life $(N=411, p<.05)$

\begin{tabular}{lccc}
\hline & Age & $\begin{array}{c}\text { Multi- } \\
\text { morbidity }\end{array}$ & SWLS \\
\hline Difficulties with using public transport & 0.12 & 0.03 & 0.06 \\
\hline $\begin{array}{l}\text { Difficulties with running basic formal/administrative } \\
\text { errands }\end{array}$ & 0.27 & 0.27 & -0.20 \\
\hline Difficulties with shopping & 0.39 & 0.34 & -0.13 \\
\hline Difficulties going for a walk & 0.23 & 0.31 & -0.22 \\
\hline Difficulties with cleaning one's home & 0.31 & 0.32 & -0.15 \\
\hline Difficulties with independent preparation of meals & 0.20 & 0.24 & -0.12 \\
\hline Difficulties with getting dressed independently & 0.13 & 0.16 & -0.10 \\
\hline Difficulties with self-grooming & 0.19 & 0.19 & -0.14 \\
\hline Difficulties with small repairs and renovations & 0.26 & 0.16 & -0.14 \\
\hline
\end{tabular}

A large body of data was obtained in this study regarding seniors' assessments of quality of health services. The problem of discrimination of older individuals by medical personnel was included in the interview. Most respondents, regardless of locality, did not report experiencing such discrimination. Unfortunately, the fraction of respondents who described instances of experiencing discrimination ranged from a fifth of those living in villages to a third of those living in big cities. These experiences occurred with frequency ranging from moderate to very frequent (Fig. 2).

Analysing barriers in the everyday functioning of older adults has shown that the greatest such barrier is coping with their diseases. Inhabitants of big cities can rely less on their close family members for care than can their peers from small towns and villages. It is a sign of the times that Poland, which used to be an example of a country which relied on the family as the main source of support for seniors, as a result of the pension and annuities reform and economic mobility of younger generations, only slowly approaches the problem of deficit of care and help for its oldest citizens. At the same time, the older citizens of Poland expressed no demands from the State with regards to providing them with proper care and adapting the scope of healthcare to their needs. Such expectations would be justified, and are natural to communities of seniors in highly developed countries. This is shown in the low percentage of answers identifying difficulty accessing care institutions (including health services) (Fig. 3).

Analysis of strategies for coping with difficult situations, such as a disease, shows that it is most common for older individuals who live in small towns, followed by those living in villages, to compensate for the low frequency of physician consultations by self-medication practices, including the frequent use of analgesics. The situation of seniors living in big cities is significantly more favourable. Although they undergo more intensive pharmacotherapy, this therapy is under the control of a physician and more individualised. Its effectiveness proves the fact that this subgroup has by far the lowest level of use of painkillers, as proved by the ANOVA analysis (Wilk's Lambda $=0.965, \mathrm{~F}(6,900)=2,678$; $\mathrm{p}=0,014$ ) (Fig. 4).

The analysis of environmental resources of older adults are based on self-reporting. The subjects assessed them with a choice of five responses ( 1 - never; 5 - always). The collected data shows that the family is a substantial source of care, but its fundamental caregiving function is clearly preserved mostly in villages. Seniors living in big cities often cannot count on support and help from their closest family members. The available help services guaranteed by the State in the form of visiting nurses, social caregivers, or financial help, is marginal, if it exists at all (Fig. 5).

It is worth highlighting that in the range and diversification of help resources, the quality of life of seniors who live outside big cities is worse, with the exception of family support, which is better (differences were significant; Wilk's Lambda $=0.928$, $\mathrm{F}(10,886)=3,393 ; \mathrm{p}=0.0002)$.

The problem of older individuals' self-reported barriers to usage of medical services in Poland still exists. The collected data proved significant differences $(\mathrm{F}(2,451)=3,614, \mathrm{p}=0.0277)$ in seniors' evaluation of the frequency of difficulties in using medical services, in villages, small towns, and big cities (Fig. 6). Subjects assessed the problem with a choice of five responses ( 1 - never; 5 - always). 


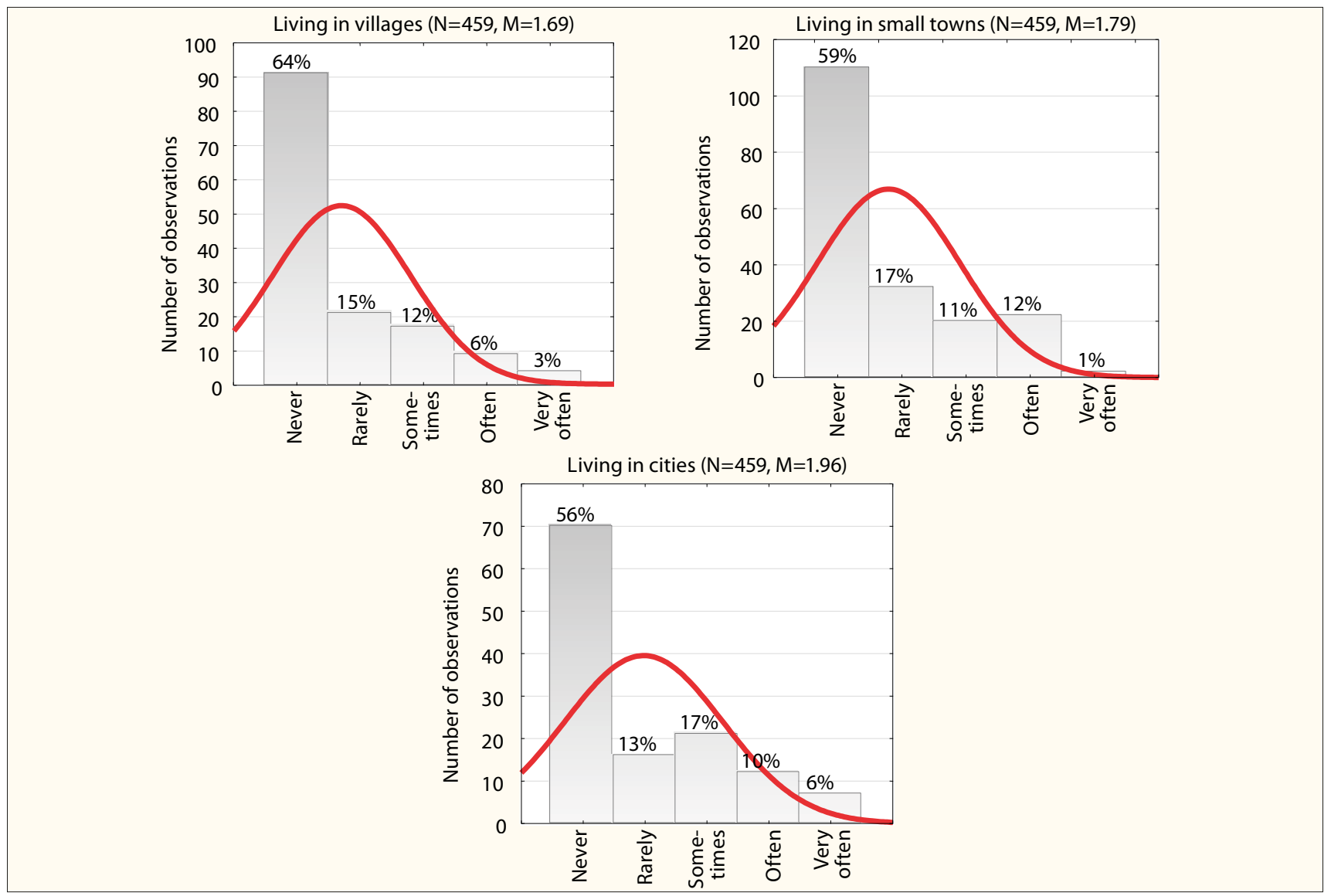

Figure 2. Experience of discrimination in the health sector by older individuals living in villages, small towns, and big cities

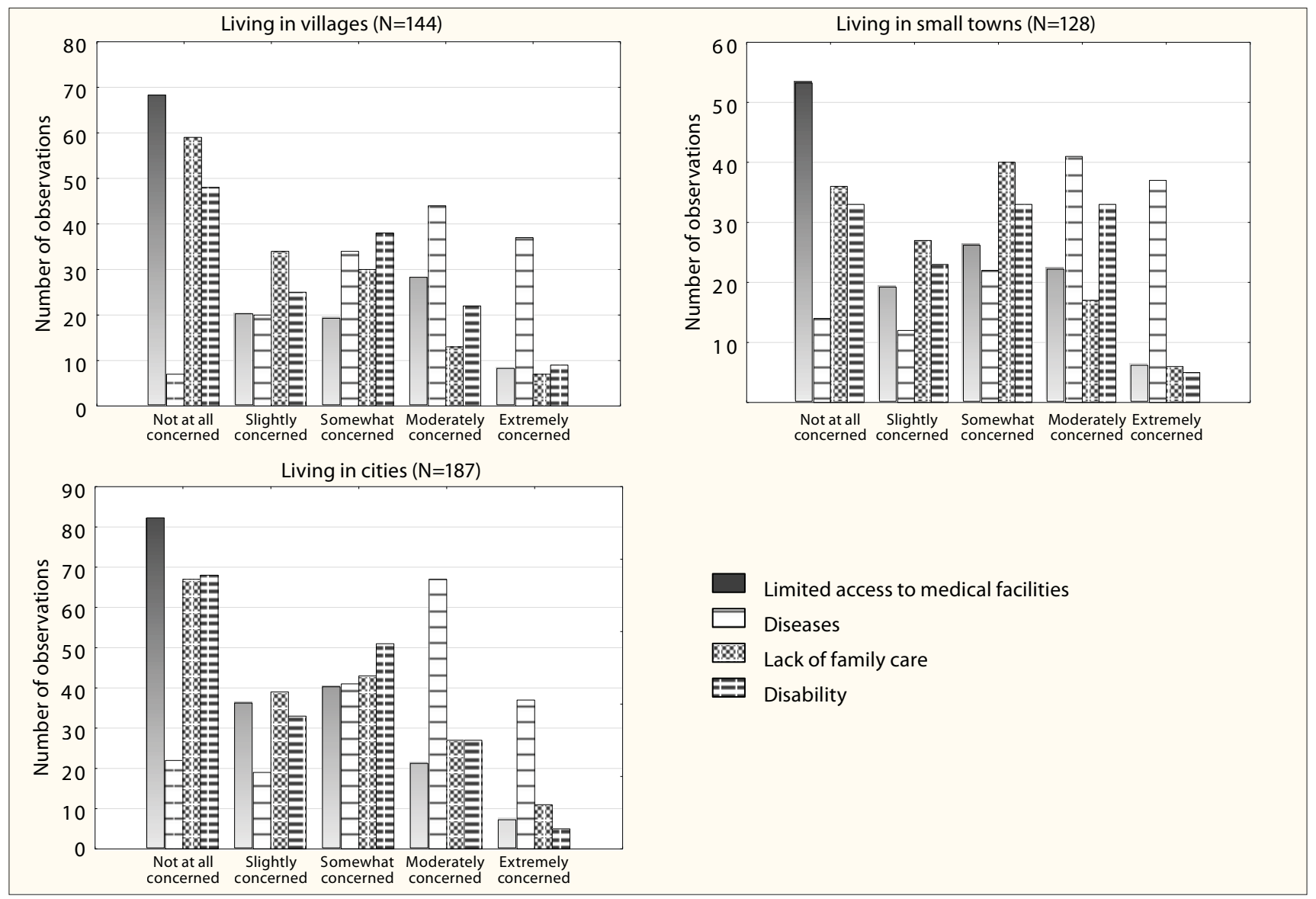

Figure 3. Which problems affect older individuals in your community, and to what extent do they concern you? 


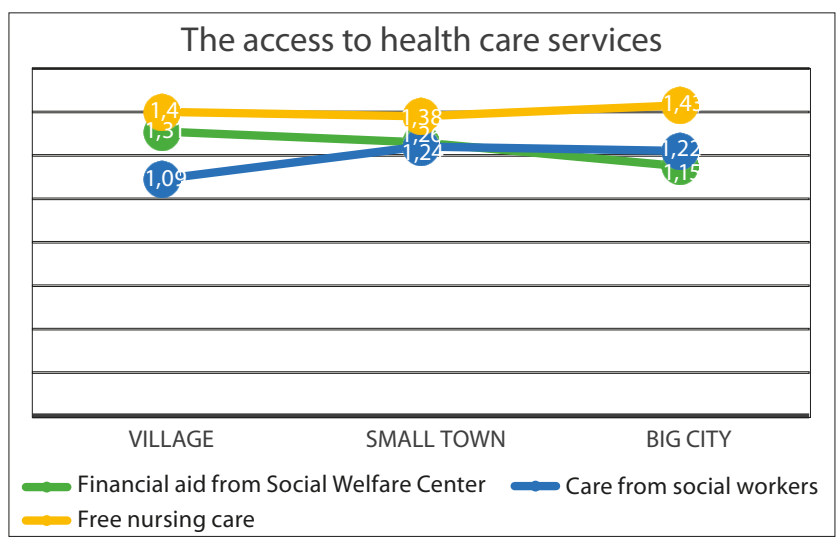

Figure 4. Bi-annual checkup with a physician, taking analgesics in the preceding week, and polypharmacy among the participants, by locality

\section{Frequency and scope of help used by the seniors}
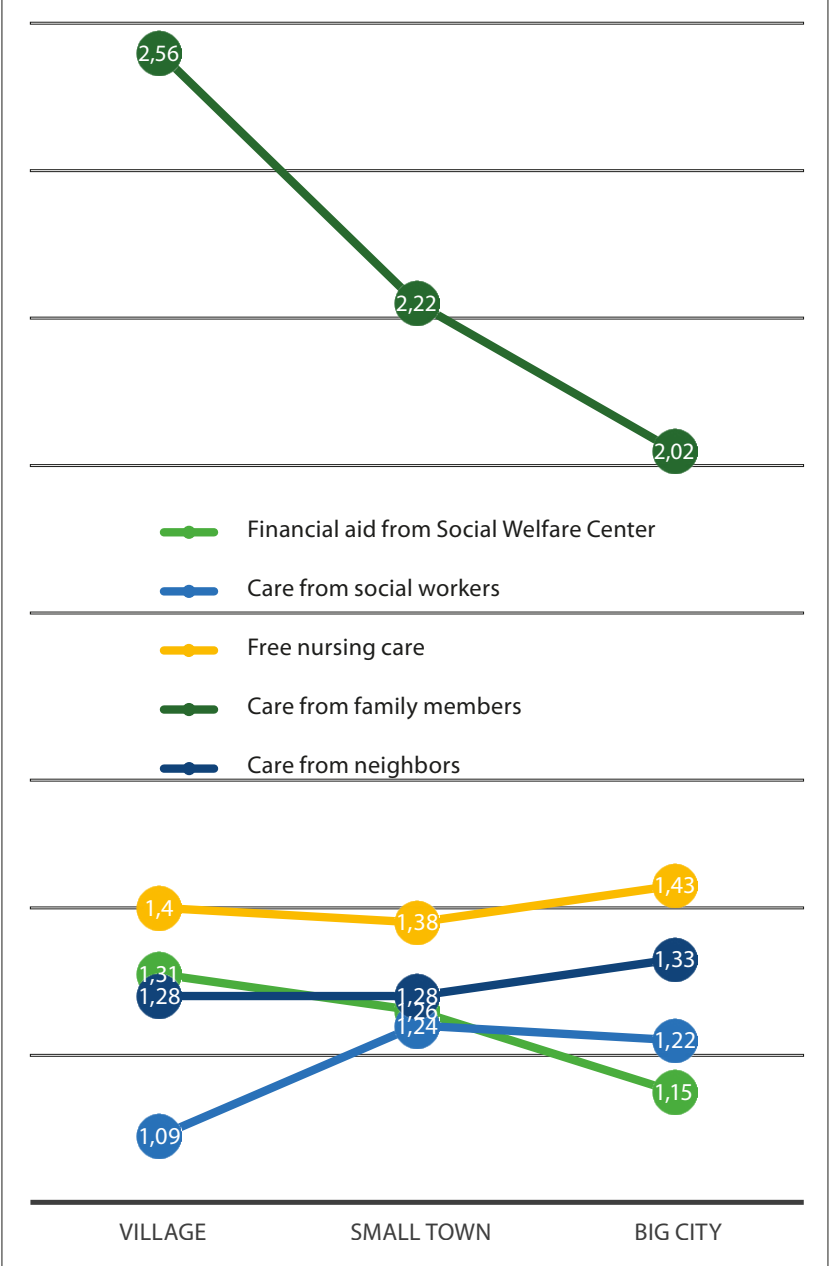

Figure 5. Frequency and scope of help used by seniors living in villages, smal towns, and big cities

\section{DISCUSSION}

]The model of successful healthy ageing has led to a revised understanding of the geriatric patient's functioning. The geriatric patient-centered view is more favoured than the traditional disease-centreed view [14]. This change is visible

\section{Self-reported barriers to usage of medical services}

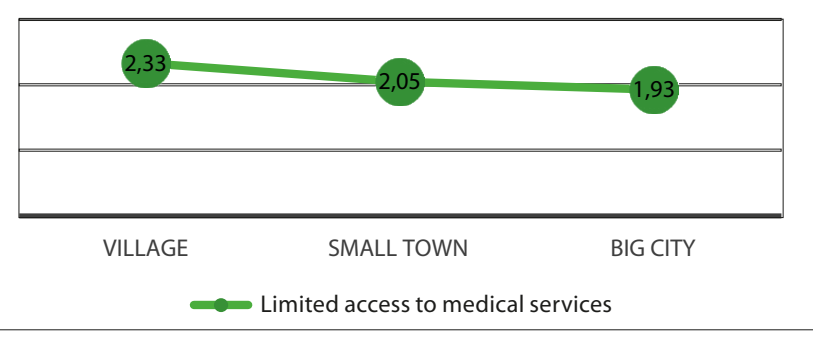

Figure 6. Responses of seniors concerning difficulties accessing and using medical services, in villages, small towns, and big cities

even in critical areas, such as caring for patients suffering from dementia [15], which is an achievement of the last two decades. However, this progress is much more visible in research papers and publications than in common practice $[16,17]$. In the everyday life of geriatric patients, diseases are usually treated symptomatically using the cheapest, routine procedures. Interventions are focused on fighting symptoms, and comprehensible and effective diagnoses are rare.

Fragmentary and fickle financial cuts do not improve the condition of the health sector in the area of geriatric practise. The problem of huge, consistently underestimated costs associated with chronic diseases in old age, incurred by patients, their families, local communities and the State, remains ongoing for many countries, including Poland $[18,19]$.

Despite these limitations, it has been observed that the subjective assessment of the health of Poles has improved in recent years, i.e. between population studies in 2009 and 2014 [20]. The results turned out to be only a little lower than the results of seniors in the USA $(M=24.40, S D=6.99)$ [12]. A Polish normalisation sample ( $N=555$, aged 20-55) had no subjects at the senior age that could be compared with the presented results [13]. The findings of the presented study are in line with this, especially in the context of the investigated overall level of quality of life, multimorbidity, and polypharmacy. The results are also in line with the global trend of promoting successful ageing at home. Of course, a generalization of the entire population would not be justified, but the first phase of Polish old age (i.e. before the age of 75, as per WHO) seems to correspond to the model of successful ageing. However, when interpreting them, one ought to refer to cross-cultural studies [21], to the context of the lives of Polish older adults, and to the deficits in health care, otherwise the interpretation may be harmful - a naive, overly positive interpretation may slow down the inefficient and delayed reform of the geriatric health care sector in Poland. The data presented in the current study about the lack of fulfilment of the needs of older individuals in terms of health and healthcare show that the pro-senior reform undertaken to-date is a patchwork of local initiatives, with marginal efficacy.

This study has shown that the safety of the older adults in the area of health, understood as appropriate support in the disease process and full diagnostics, appropriate pharmacotherapy, pain management, and optimisation of the overall quality of life, is still beyond their reach. There is a lack of specialised personnel to provide care for older adults in their place of residence. The problem of the low number of visiting nurses, who can unburden GPs 
and react to the needs of geriatric patients on an ongoing basis, is clearly visible. This has been indicated by nurses themselves $[22,23]$. The results discussed in this study should be treated as the active participation of seniors in the debate on the role of visiting nurses. The respondents reported unsatisfactory access to nursing services, which they assessed as necessary. Lack of specialized physicians caused even greater frustration and undoubtedly posed a threat to the wellbeing of ageing individuals. Contact with GPs was not satisfactory. Difficulty in accessing and using health services is a serious barrier to prophylaxis and appropriate management of the ageing process for inhabitants of small towns and villages. Respondents compensated for the lack of specialists through self-medication. This tendency was indirectly revealed through their frequent use of analgesics. Pain and its importance for quality of life of older adults is becoming more pronounced in the world literature [24, 25], whereas in Poland, in geriatric practice, it is marginalised. Knowledge about the negative influence of polypharmacy [26] among ageing individuals is small. The situation is worsened by the media, who advertise diet supplements and other non-prescription (and thus beyond physicians' control) drugs: vitamins, mineral preparations, and dietary supplements (used by over $25 \%$ of adults [20]). Taken all at once and with no regard to the physiological efficiency of the organism, they often worsen, rather than improve, the condition of seniors.

Among the currently well-diagnosed diseases are: cardiovascular diseases and some types of cancers, but prevention, early diagnosis, and concern about high quality of long-term care are still weak sides of the underfinanced health sector. Waiting times for diagnostic procedures, medical procedures, and consultations are usually months, frequently even more than a year [20]. The inefficiency of the system for a geriatric patient is equivalent to treatment failure, significant decline in quality of life, and even premature death. Reorganisation of the health service, especially in the area of management and finances, is a difficult task, and without doubt a long-term one. The role of the State must extend beyond narrow interventions aimed at resolving a crisis. It is possible to positively influence the quality of life of an ageing individual through interventions from health policy, as it is broadly understood. This has been shown by Thomas R. Frieden [27, 14] in the health impact pyramid. The value of such interventions is shown by studies, which we refer to too rarely, showing that $5-15 \%$ of one's health is determined by genetic factors, $5-10 \%$ by physical environment, $20-25 \%$ by social context, only $10-20 \%$ by interventions of remedial medicine, and as much as $50 \%$ by an individual's lifestyle [28].

\section{CONCLUSIONS}

The health care system, especially the geriatric sector, still seriously fails to address the real needs of patients $[29,30$, $31,32,33,34]$. The number of primary care physicians, specialists, and other health care practitioners along with the appropriate number of beds for geriatric patients, are insufficient. Strategies implemented in order to increase the effectiveness of medical care outside of Poland [35], including interdisciplinary interventional teams, integrated care pathways, or analysis of generic and/or specific patient reported outcome measures, are just interesting bits of gerontological literature to Polish practitioners. An inefficient system dumps the burden of caring for geriatric patients on their families. At the same time, the increasing economic mobility of young people, crisis of attachment, and a number of other factors, significantly lower the readiness of relatives to care for their ageing relations.

The anxiety of a geriatric patient about their body's inefficiency and weakness increases. At the moment, the number and scope of health services they are guaranteed is insufficient, and there are still no ideas for dealing with the increasing deficit. Calls for the de-institutionalization of care for older adults, especially in the light of the expected increase in the numbers of patients with dementia, are reckless and socially harmful. The expectation that the State will secure care for the older adults is naive. The only responsible action to take is to promote responsible and efficient partnership in the area of long-term care for geriatric patients between practitioners (geriatric specialists, nurses, social workers, and physiotherapists), relatives, society, and the seniors themselves $[4,36]$. In order to achieve this, it is necessary to be open to a wider discussion about the diversification of needs and resources of geriatric patients living in villages and in big cities.

\section{REFERENCES}

1. Haber D. Health care for an aging society. Cost-conscious community care and self-care approaches. Routledge, London \& New York. 1989.

2. Burns LR, D'Aunno T, Kimberly JR. Globalization and its many faces: the case of the health sector. [in:] H. Gatignon, J.R. Kimberly, R.E. Gunther (eds.) The INSEAD-Wharton alliance on globalizing. Strategies for building successful global businesses, s.395-421. Cambridge University Press, Cambridge. 2004.

3. World Health Organization. Preventing Chronic Diseases: a Vital Investment. Geneva. 2005.

4. Fouché Ch. Partnering in the field of chronic care service provision. [in:] Beddoe L, Maidment J (eds.). Social work practice for promoting health and wellbeing. Critical issues, p. 218-229. Routledge, London \& New York. 2014.

5. Buliński L. Polityczne postrzeganie problematyki starzenia się obywateli: obraz życzeniowy [Political perception of the problems of citizens' ageing: wishful thinking]. [in:] Buliński L (ed.). Realność złego starzenia się. Poza polityczną i społeczną powinnością [The reality of bad ageing. Beyond political and social correctness], 11-22. Wydawnictwo A. Marszałek, Toruń. 2015. [in Polish]

6. Błachnio A. Tele-geriatria a jakość życia seniorów [Tele-geriatry and the quality of life of seniors]. Pedagogika Rodziny 2016; 6(2): 167-176. [in Polish]

7. Derejczyk J, Bień B, Kokoszka-Paszkot J, Szczygieł J. Gerontologia i geriatria w Polsce na tle Europy - czy należy inwestować w ich rozwój w naszym kraju? [Gerontology and geriatric in Poland as compared to Europe - should we invest in their development in our country?] Gerontologia Polska 2008; 16(3): 149-159. [in Polish]

8. NIK (Naczelna Izba Lekarska) (2017). Zestawienie liczbowe lekarzy i lekarzy dentystów wg dziedziny i stopnia specjalizacji; stan na 30.11.2017 [Numerical comparison of doctors and dentists by field and degree of specialization; condition on November 30, 2017]. http://www. nil.org.pl/_data/assets/pdf_file/0004/124294/Zestawienie-nr-04.pdf (access: 30.12.2017) [in Polish]

9. Bień B. Opieka geriatryczna w perspektywie starzenia się ludności w Polsce [Geriatric care in the context of population ageing in Poland]. [in:] Hrynkiewicz J (ed.). O sytuacji ludzi starszych [About the situation of older adults], 151-158. Rządowa Rada Ludnościowa, Warszawa. 2012. [in Polish]

10. Błędowski P, Maciejasz M. Rozwój opieki długoterminowej w Polsce - stan i rekomendacje [Development of long-term care in Polandcurrent state and recommendations]. Nowiny Lekarskie 2013; 82(1): 61-69. [in Polish] 
11. Dubiel M, Klich-Rączka A. Specyficzne potrzeby lecznicze osób starszych a kształcenie geriatrów. Dlaczego geriatria jest specjalizacja ważną i dlaczego ciągle brakuje geriatrów? [Specific medical needs of older individuals and education of specialists of geriatry. Why is geriatry an important specialisation, and why is there still a shortage of specialists of geriatry?] Zdrowie Publiczne i Zarządzanie 2011; IX(1): 101-109. [in Polish]

12. Diener E, Emmons RA, Larsen RJ, Griffin S. The Satisfaction With Life Scale, Journal of Personality Assessment; 1985; 49: 71-75.

13. Juczyński Z. Narzędzia pomiaru w promocji i psychologii zdrowia [Measurement tools for promotion of health and health psychology] Pracownia Testów Psychologicznych PTP, Warszawa. 2001. [in Polish]

14. IOM (Institute of Medicine). Women's Health Research: Progress, Pitfalls, and Promise. The National Academies Press, Washington, DC. 2010.

15. Stokes G, Goudie F (eds.). The essential dementia care handbook. Routledge, London \& New York. 2017.

16. Buliński L, Błachnio A. Health in old age, and patients' approaches to telemedicine in Poland. Ann Agric Environ Med. 2017; 24(2): 322-328.

17. Buliński L, Boike D. Chorzy przewlekle [Chronically-ill individuals]. Polityczne kwestie nieobecności w polskiej ochronie zdrowia [Political issues of absence in Polish healthcare]. Wydawnictwo Ateneum-Szkoły Wyższej, Gdańsk. 2017. [in Polish]

18. IOM (Institute of Medicine) Living well with chronic illness: A call for public health action. The National Academies Press, Washington, DC. 2012 .

19. National Academies of Sciences, Engineering, and Medicine. (2016). Policy and research needs to maximize independence and support community living: Workshop summary. The National Academies Press, Washington, DC. 2016. http://www.nap.edu/read/21893/chapter/1 (access: 10.07.2016)

20. GUS (Główny Urząd Statystyczny) Raport: Zdrowie i zachowanie zdrowotne mieszkańców Polski w świetle Europejskiego Ankietowego Badania Zdrowia (European Health Interview Survey) 2014 r. [Health and health behaviours of inhabitants of Poland in light of the European Health Interview Survey of 2014]. http://stat.gov.pl/obszary-tematyczne/ zdrowie/zdrowie/zdrowie-i-zachowania-zdrowotne-mieszkancowpolski-w-swietle-badania-ehis-2014,10,1.html (access: 13.07.2016) [in Polish]

21. Hank K. How successful do older European age? Findings from SHARE. Journals of Gerontology: Series B, 2011; 66B(2): 230-236.

22. Palczewska A. System opieki długoterminowej a zapotrzebowanie na ten rodzaj świadczeń [Long-term care systems and demand for such services]. Problemy Pielęgniarstwa 2010; 18(2): 198-206. [in Polish]
23. Bielawska J. Rola pielęgniarki w opiece długoterminowej [The role of nurse in long-term care]. Zeszyty Naukowe Państwowej Wyższej Szkoły Zawodowej im. Witelona w Legnicy 2015; 15(2): 7-20. [in Polish]

24. Molzahn A, Skevington SM, Kalfoss M, Schick Makaroff K. The importance of facets of quality of life to older adults: an international investigation, Qual Life Res 2010; 19: 293-298.

25. Molton IR, Terrill AL. Overview of Persistent Pain in Older Adults. American Psychologist 2014; 69(2): 197-207.

26. Cielecka-Piontek J, Rajska-Neumann A, Wieczorowska-Tobis K. Wielolekowość w populacji geriatrycznej [Polypharmacy in the geriatric population]. Nowiny Lekarskie 2006; 75(1): 13-17. [in Polish]

27. Frieden TR. A framework for public health action: the health impact pyramid. American Journal of Public Health 2010; 100(4): 590-595.

28. Bień B. Sytuacja zdrowotna osób w podeszłym wieku [The health status of older individuals]. [in:] Grodzicki T, Kocemba J, Skalska A (eds.). Geriatria z elementami gerontologii ogólnej [Geriatry with elements of general gerontology]. p.42-46. Via Medica, Gdańsk. 2006. [in Polish]

29. Cuddy AJC, Norton MI, Fiske ST. This old stereotype: the pervasiveness and persistence of the elderly stereotype. Journal of Social Issues 2005; 61(2): 265-283.

30. National Research Council (US) Committee on Aging Frontiers in Social Psychology, Personality, and Adult Developmental Psychology; Carstensen LL, Hartel CR, (eds.). When I'm 64. National Academies Press (US), Washington. DC. 2006.

31. Błachnio A. Starość non profit [Non-profit old age]. Wolontariat na Uniwersytetach Trzeciego Wieku w Polsce i na świecie [Volunteering in Universities of the Third Age in Poland and around the world]. Wydawnictwo UKW, Bydgoszcz. 2012. [in Polish]

32. Błachnio A, Buliński L. Prejudices and elderly patients’ personality the problem of quality of care and quality of life in geriatric medicine. Med Sci Monit. 2013; 19: 674-680.

33. Hwang U, Platts-Mills T. Pain management in the elderly [in:] Kahn JH, Magauran BG, Olshaker JS (eds.). Geriatric Emergency Medicine. Principles and Practice. p.69-76. Cambridge University Press, Cambridge. 2014

34. Ziółkowski A, Błachnio A, Pąchalska M. An evaluation of life satisfaction and health. Quality of life of senior citizens. Ann Agric Environ Med. 2015; 22(1): 147-151

35. Cox CL, Hill MC, Lack VM. Advanced practice in healthcare. Skills for nurses and allied health professionals. Routledge, London \& New York. 2012.

36. Cabak A. Expectations of the patients referred to physical and rehabilitation medicine doctors. Acta Neuropsychol. 2017; 17(1): 13-20. 